\title{
マスコンクリートの基礎的物性に関する研究
}

\section{STUDIES ON THE FUNDAMENTAL PROPERTIES OF MASS CONCRETE}

\author{
竹 下 治 之* \\ By Haruyuki TAKESHITA
}

\begin{abstract}
It is important that we fully understand physical properties of concrete in thermal stress analysis of mass concrete. The purpose of this paper is to investigate such properties of mass concrete. I used two kinds of aggregates and several sorts of mix proportions of concrete in this investigation, and obtained compressive strength, tensile strength, modulus of elasticity, Poisson's ratio, flexural strength and coefficient of thermal expansion.

Also I compared splitting strength with tensile strength obtained by pure tension test.

In order to understand quantitatively and qualitatively these properties of mass concrete, I related them to maturity and curing ages. I moreover refer to the method of estimation of these properties from compressive strength obtained by the specimens in water curing at $20^{\circ} \mathrm{C}$.
\end{abstract}

\section{1. まえがき}

近年, 土木および建築分野におけるコンクリート構造 物の大型化に伴い，いわゆるマスコンクリートのひびわ れの発生が問題となってきている. すなわち，このよう なひびわれは, 構造物の安全性, 耐久性, 遮水性などを 損なうため, 可能な限りその発生を防止するか, あるい は許容ひびわれ幅以内に制限することが要求される.

一般に, コンクリート構造物で, ひびわれ発生の原因 としては, 乾燥収縮, 実荷重, 温度応力によるひびわれ 等があるが, マッシブなコンクリート構造物では, セメ ントの水和熱による熱膨張および収縮過程の体積変化に 基づく温度応力が主要因であることが多い.

しかし，マスコンクリートの温度ひびわれの検討にお いては, 以下のような未解明な点も多く, その温度応力 を正確に推定することは, 現状では比較的難しい.

a ）マスコンクリートの若材令における諸物性

b ）内部および外部拘束応力の発生メカニズム, お よびこれらの経時変化

c ） マスコンクリートのひびわれ発生条件

このように, マッシブなコンクリート構造物の温度応

* 正会員 工修 日本国土開発(株)技術研究所

( ₹243-03 神奈川県愛甲郡爱川町中津 4036-1)
力解析においては, 種々の問題点が現存するが, まず, 的確なマスコンクリートの諸物性値の把握が重要な問題 となってくる.

岡田ら ${ }^{1)}$ は, 種々の温度履歴下におけるマスコンク リートの基礎的特性について考察しているが,この物性 值に関して定性的かつ定量的に取り扱った研究は少ない ように思われる。

このような現状に対し, 本研究では, マスコンクリー トの硬化過程における諸物性を明らかにすることを目的 として, 骨材および配合を変え基礎的試験を行った。対 象亡した物性値は, 圧縮強度, 引張強度, 弾性係数, ポ アソン比, 曲げ強度および熱膨張係数であり, 特に, 温 度応力解析において重要と考えられる引張強度に関して は, 割裂引張試験のほか, 純引張試験も併せて行い, 両 者を比較検討した.

また,これらの物性值は, その特性を定量かつ定性的 に把握するため, 時間依存因子として, 積算温度および 有効材令と関連づけるとともに，これらの諸物性值を一 般的な標準水中養生供試体の圧縮強度をもとに推定する 方法を示した.

\section{2. 実 験 概 要}

\section{（1）使用材料}


セメントは小野田社製の普通ポルトランドセメント を, 混和剤は日曹マスタービルダーズ社の遅延型 $\mathrm{AE}$ 減水剤ポゾリス No. 8 を用いた。使用骨材を表一1 に示 す.

\section{（2）配合}

配合は骨材の相違による物性值の差異を検討すること を目的として，表一1に示す $\mathrm{K} . \mathrm{T}$ シリーズを主体とし， 基準強度を 3 種類とした。また，F.S シリーズは熱膨 張係数測定試験のみに使用した。

\section{（3）供 試 体}

圧縮および割裂試験用供試体は，いずれも $10 \phi \times 20$ $\mathrm{cm}$ の円柱供試体を，曲げ試験用供試体は $10 \times 10 \times 40$ $\mathrm{cm}$ の直方体供試体を用いた。純引張および熱膨張係数 測定用供試体を，それぞれ図一1および図一2に示す.

\section{（4）暴生方法}

岡田ら"によれば，マスコンクリートの物性值は，温 度履歴によらず，ほぼ積算温度 $M=\Sigma(10+T) \Delta t(こ$ こに, $T$ : 養生温度 $\left({ }^{\circ} \mathrm{C}\right), \Delta t:$ 経過時間 $\left.(\mathrm{h})\right)$ をパラメ一

\section{表一1 使用骨材}

\begin{tabular}{|c|c|c|c|c|c|c|c|c|}
\hline \multirow{2}{*}{$\because y ー x z$} & \multicolumn{4}{|c|}{ 粗 } & 田 & \multicolumn{2}{|c|}{ 骨林 } & \multirow{2}{*}{ 尚 } \\
\hline & 䒺 & FM & & 比畺 & \% & $\mathbf{F M}$ & 比重 & \\
\hline $\mathrm{K}$ & 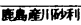 & 6.54 & 25 & 2.59 & 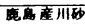 & 2.67 & 2.60 & 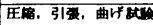 \\
\hline$T$ & 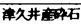 & 6.48 & 25 & 2.61 & 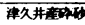 & 3.13 & 2.59 & 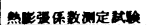 \\
\hline$F$ & 坛墥利 & 6.56 & 25 & 2.60 & 士士川就川的 & 2.97 & 2.59 & \\
\hline s & 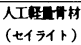 & 6.15 & 20 & 1.32 & 竟川础 & 2.67 & 2.60 & 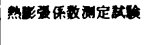 \\
\hline
\end{tabular}

\begin{tabular}{|c|c|c|c|c|c|c|c|c|c|c|c|}
\hline & 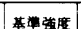 & & & 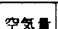 & 七 & 钟用材針 & 単 & & 位 & I & $\left(\mathrm{kg} / \mathrm{m}^{\prime}\right)$ \\
\hline 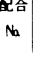 & $\left|\begin{array}{c}\sigma_{c} \\
\mathrm{~kg} \mathrm{v} / \mathrm{cm})\end{array}\right|$ & 使用踢 & $(\mathrm{cm})$ & $(\%)$ & 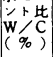 & $\begin{array}{l}\mathrm{s} / \mathrm{a} \\
(\% 0)\end{array}$ & $\begin{array}{l}\text { 水 } \\
\mathrm{W}\end{array}$ & $\begin{array}{c}\text { tAン } \\
\mathrm{C}\end{array}$ & $\begin{array}{c}\text { 細骨材 } \\
\mathrm{S}\end{array}$ & $\begin{array}{c}\text { 柤骨材 } \\
G\end{array}$ & 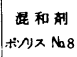 \\
\hline $\mathrm{K}_{\mathrm{J}}$ & 250 & \multirow{3}{*}{ K } & \multirow{8}{*}{$8 \pm 1$} & \multirow{8}{*}{$4 \pm 1$} & 64.5 & 41.0 & 145 & 225 & 793 & 11137 & 0.563 \\
\hline $\mathrm{K}_{2}$ & 350 & & & & 49.4 & 403 & 146 & 296 & 757 & 11114 & 0.740 \\
\hline$K_{3}$ & 450 & & & & 40.3 & 39.7 & 138 & 342 & 736 & 11116 & 0.855 \\
\hline$T_{1}$ & 250 & \multirow{3}{*}{$T$} & & & 64.9 & 46.3 & 169 & 260 & 850 & 993 & 0.650 \\
\hline$T_{2}$ & 350 & & & & 50.6 & 44.3 & 163 & 322 & 798 & 10010 & 0.805 \\
\hline$T_{3}$ & 450 & & & & 41.5 & 42.3 & 167 & 402 & 730 & 1002 & 1.005 \\
\hline $\mathrm{F}$ & 350 & $F$ & & & 40.8 & 41.5 & 153 & 375 & 740 & 1045 & 0.938 \\
\hline $\mathrm{S}$ & 350 & $\mathrm{~S}$ & & & 42.0 & 42.7 & 172 & 410 & 731 & 498 & 1.025 \\
\hline
\end{tabular}

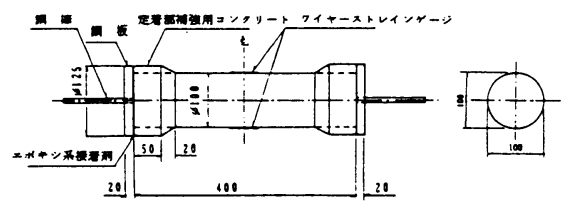

図一1純引張試硂用供試体

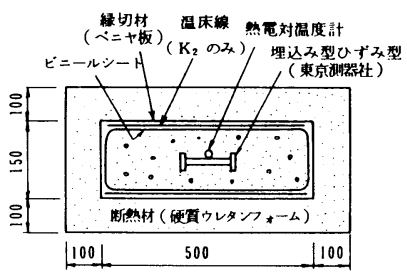

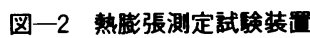

ターとして整理できることが示されているので，熱膨張 係数測定用供試体以外のすべての供試体は，材令 1 日で 脱型後，マスコンクリートの状態と近似させる目的で, ビニールシートで覆って水分の移動を防ぎ， $30 \pm 1^{\circ} \mathrm{C}$, $90 \pm 5 \% \mathrm{RH}$ 恒温恒湿室で気中養生を行った。また，同 時に作成した圧縮および割裂試験用供試体については, マスコンクリートの物性值と比較検討する目的で, $20 \pm$ $1^{\circ} \mathrm{C}$ の恒温水槽でも標準水中荃生を行った.

\section{（5）試験方法}

a ）圧縮および割裂引張強度試験

試験は表一2 $2 K_{1}, K_{2}, K_{3}, T_{1}, T_{2}, T_{3}$ の 6 配合について, $20^{\circ} \mathrm{C}$ 水中養生および $30^{\circ} \mathrm{C}$ 気中養生とも, 材令 $1,2,3,5,7,14,28$ 日で行い, 圧縮強度 $\sigma_{c}$, 割裂引張強度 $\sigma_{s t}$ を測定した。同時に，王縮試験では破壊までの縦お よび横ひずみを測定して，破壊荷重の $1 / 3$ 点での割線弾

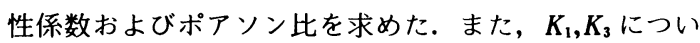
ては, 24 時間以内のごく若材令における圧縮強度およ び弾性係数も測定した.

\section{b ) 純引張強度試験}

試験には $K_{1}, K_{3}, T_{1}, T_{3}$ の 4 配合を用いた。供試体は図 一1に示すように, 引張用治具としてねじ穴を設けた $125 \phi \times 20 \mathrm{~mm}$ の鋼板を両端に配し，鋼板とコンクリー 卜の接着をよくする目的で, 図のような定着部の補強を 行い, 材令に合わせてエポキシ樹脂系接着剤を用いて接 着した。供試体中央部に 2 枚のひずみゲージを貼付し破 壊まで荷重とひずみをXYレコーダーで記録し，純引 張強度 $\sigma_{p t}$, 極限引張ひずみ $\varepsilon_{t u}$ および引張弾性係数 $E_{t}$ (応力とひずみ関係がほぼ直線となるため, 破壊の $3 / 4$ 点の割線弾性係数を用いた）を測定した。なお，載荷速 度は約 $0.1 \sim 0.2 \mathrm{kgf} / \mathrm{cm}^{2}$ で行った.

c ) 曲げ試験

試験は $K_{1}, K_{3}$ の配合について, スパン $10 \mathrm{~cm}$ の 3 等 分載荷とし, JIS A 1106 に準じて曲げ強度 $\sigma_{b}$ を求めた.

d ) 熱膨張係数測定試験

試験は $K_{1}, K_{2}, K_{3}, T_{3}, F, S$ について行った。図一2 に示 す位置に埋込み型ひずみ計および熱電対を埋設し，コン クリートのひずみと温度を計測した。供試体は，マスコ ンクリートの熱拡散および水分移動状態と同様にするた め, 図に示すように，周囲を硬質ウレタンフォームおよ びビニールシートで覆い, 膨張・収縮が自由にできるよ う, コンクリート打設 $3 \sim 4$ 時間後に凝結が始まり，コ ンクリートが自立する状態で周辺の縁切板の引抜きを 行った後, $20 \pm 1^{\circ} \mathrm{C}, 90 \pm 5 \% \mathrm{RH}$ 恒温恒湿室に静置した. 試験は, コンクリート打設後の温度上昇時および下降時

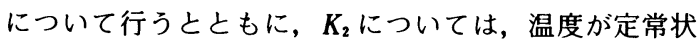
態に降下した後, 温床線により供試体温度を強制的に変 化させた場合についても行った. 


\section{3. 結果および考察}

\section{（1）圧縮強度および割裂引張強度試験}

a) 圧縮強度

圧縮強度と積算温度および有効材令の関係を図一 3 に

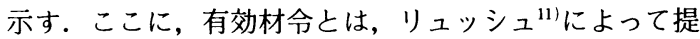
示された次に示す式で求められる材令であり， $20^{\circ} \mathrm{C}$ 一 定の条件下で養生された場合の材令に対応する（以下， これを単に材令と称す).

$t_{e}=K \cdot \Sigma[\Delta t(T+10) / 30]$ ここに,

$t_{e}:$ 有効材令 $($ 日)

$K$ : セメントの硬化速度の影響を示す係数（普通セ メント $K=1$ )

$T:$ :コンクートの温度 $\left({ }^{\circ} \mathrm{C}\right)$

$\Delta t$ : コンクリートの温度が $T^{\circ} \mathrm{C}$ である日数（日）

図一3より，K, $\mathrm{T}$ シリーズとも，各配合に対し $M \leqq 10^{4 \circ} \mathrm{C} \cdot \mathrm{h}$ の範囲においては， $\sigma_{c}$ と $M$ の間にほぼ直 線関係が認められる.ただし, 水中養生と気中養生では, 強度発現の程度が異なる。

いま,各配合の強度を図中の細線のように直線近似し， その近似式を $\sigma_{c}=A \log M-B$ とすると, 定数 $A, B$ は 図一 4 に示すように $C / W$ の一次式で示すことができ る.したがって, $M \leqq 10^{4 \circ} \mathrm{C} \cdot \mathrm{h}$ の範囲において，圧縮 強度は次式で与えられる.

( $K$ シリーズ $)$

水中： $\sigma_{c}=(101 C / W+53) \log M$

$$
-(215 C / W+229) \text {. }
$$

気中： $\sigma_{c}=(16 C / W+169) \log M$

( $T$ シリーズ)

$$
-(-58 C / W+593)
$$

水中： $\sigma_{c}=(149 C / W-35) \log M$

$$
-(338 C / W-2)
$$

気中 : $\sigma_{c}=(79 C / W+55) \log M$

$$
-(130 C / W+252)
$$

これらの式における定数 $A, B$ は, 骨材特有の值と考 えられる．このように，圧縮強度は，ある骨材に対して $C / W$ をパラメーターとして, 一般形 $\sigma_{c}=A \log M-B$ で近似されるものと推定される.

図一 5 に, 圧縮強度変化率（(水中養生強度一気中養 生強度) $\times 100 /$ 水中養生強度） $\beta$ と積算温度 $M$ の関係 を示す，各配合について変化率を図中の細線のように近 似し，一般形を $\beta=a \log M-b$ と仮定すると，定数 $a, b$ は表一 3 のようになる. これらの定数と $C / W$ の間 にも，圧縮強度の場合と同様，図一4 と同じような直線 関係が確認され，これらを整理すると，気中養生による 圧縮強度変化率は次式により示される.

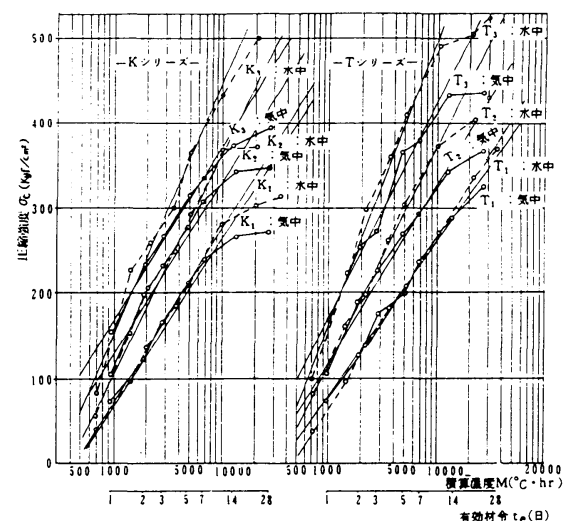

図一3圧樎強度と掼算温度および有効材令との関係

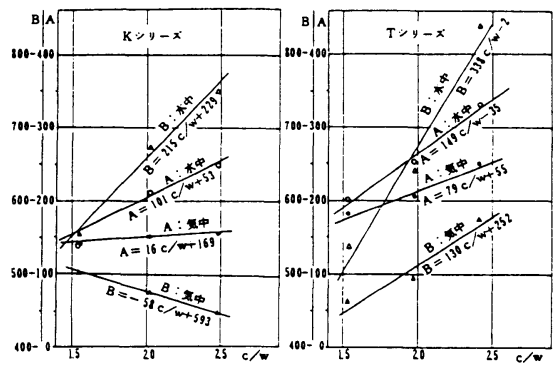

图一4 $C / W$ と係数 $A, B$ の関係

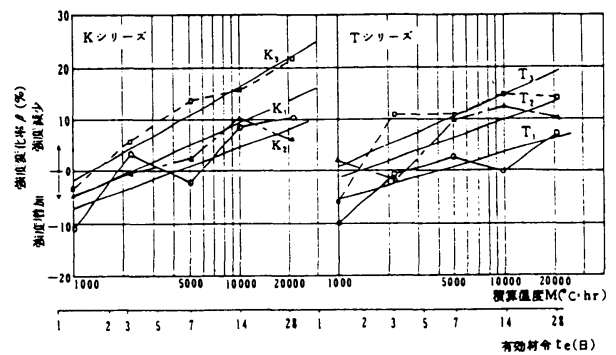

图一5 強度変化率と樌算温度および有奻材令との関係

$K$ シリーズ : $\beta=(6.1 C / W+2.4) \log M$ $-(13.3 C / W+21.3) \quad(\%) \cdots .(6)$

$T$ シリーズ : $\beta=(5.9 C / W+0.1) \log M$ $-(19.1 C / W-3.0) \quad(\%) \cdots \cdots(7)$

図一5に示されるように, 圧縮強度はほぼ $M \leqq$ $1500^{\circ} \mathrm{C} \cdot \mathrm{h}$ においては, 水中養生の場合に比較して気中 養生の方が増加し，逆に $\boldsymbol{M}$ がそれ以上になる上気中養 生の方が減少する。しかも，その減少率は富配合のコン クリートほど大きくなる傾向にある.このような現象は, 一般的に, マスコンクリートの強度発現は早いが, 長期 の強度の伸びが悪いことを示している．この実験の範囲 では，材令 28 日において，養生方法の相違による強度 低下率は約 5２0％であった。この強度低下率は，骨 


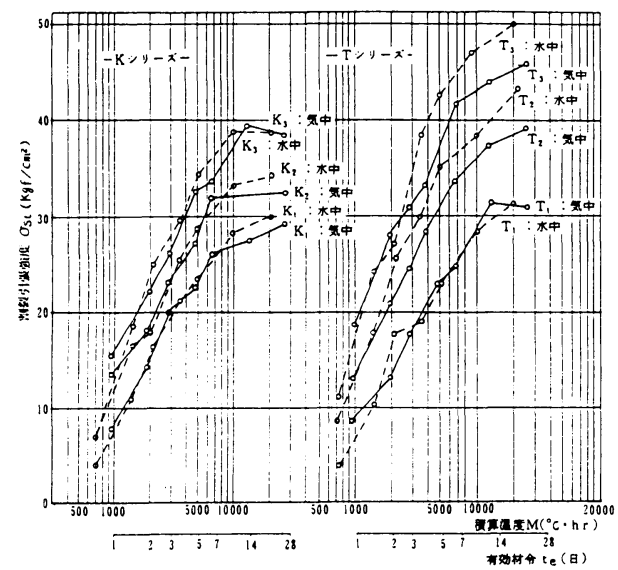

図一7 割裂引張強度と積算温度および有効材令との関係

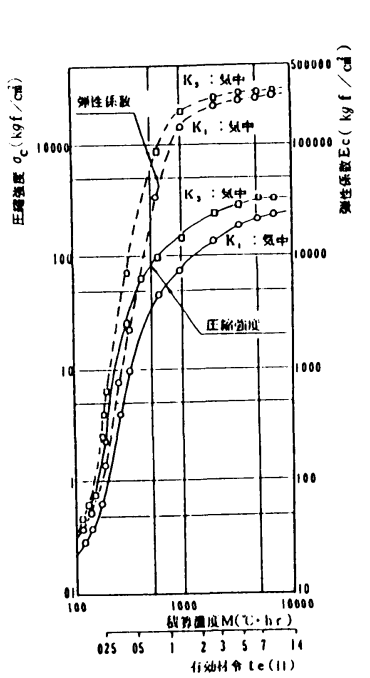

図一6 こく若材令における圧縮強度 および弾性係数と䅡算温度と の関係

\begin{tabular}{|c|c|c|c|}
\hline & $T_{1}$ & $T_{3}$ & $T_{3}$ \\
\hline$a$ & 9.2 & 11.5 & 14.3 \\
\hline$b$ & 25.3 & 36.0 & 420 \\
\hline
\end{tabular}
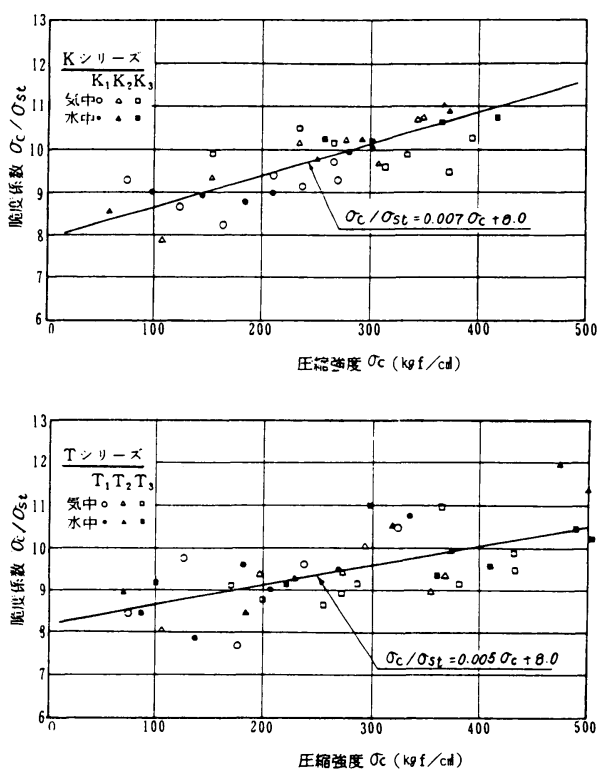

図一8 脆度係数と圧縮強度の関係
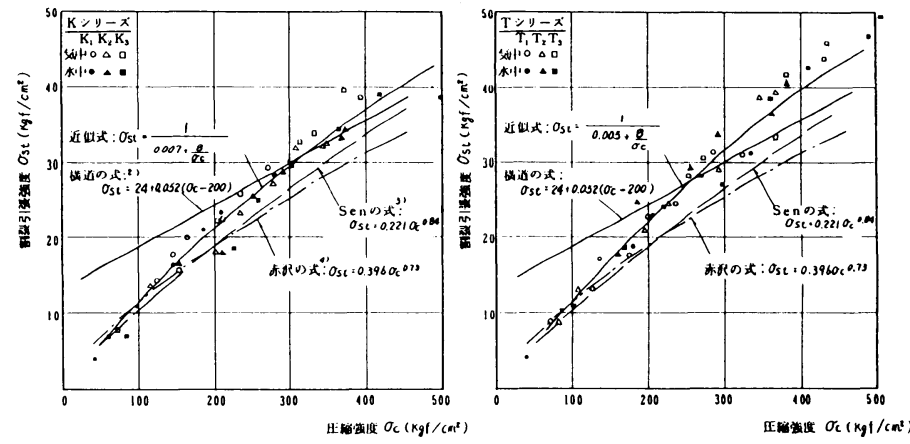

図一9 割裂引張強度と圧縮強度の関係

材あるいは温度履歴により異なるとも考えられるが，こ こに示した配合ごとの低下率は一応の目安になるものと 思われる。

また，ごく若材令を含む圧縮強度と弾性係数の発現状 況を図一6に示す，圧縮強度は積算温度が約 $500^{\circ} \mathrm{C} \cdot \mathrm{h}$, 弾性係数は約 $1000^{\circ} \mathrm{C} \cdot \mathrm{h}$ までの増加が非常に顥著であ り, しかも, それらの増加傾向はほぼ等しくなっている. このように，両者とも有効材令約 1 日までの増加がきわ めて大きいことが特徴である.

b ）割裂引張強度

図一7に割裂引張強度と積算温度および材令の関係を 示すが，両者の間には圧縮強度の場合と同様な関係がみ られる. また, 脆度係数と圧縮強度, および割裂引張強
度と圧縮強度の関係をそれぞれ図一8 および図一9に示 す.

図一8において，脆度係数と王縮強度の関係を直線に 近似すると, 次式のように与えられる.

$$
\begin{aligned}
& K \text { シリーズ : } \sigma_{c} / \sigma_{s t}=0.007 \sigma_{c}+8.0 \cdots \\
& T \text { シリーズ }: \sigma_{c} / \sigma_{s t}=0.005 \sigma_{c}+8.0 \cdots
\end{aligned}
$$

上式から, 割裂引張強度と圧縮強度の関係は次のように 表わすことができる.

$$
\begin{gathered}
K \text { シリーズ : } \sigma_{s t}=1 /\left(0.007+8 / \sigma_{c}\right) \\
T \text { シリーズ }: \sigma_{s t}=1 /\left(0.005+8 / \sigma_{c}\right)
\end{gathered}
$$

上の 2 式を図一 9 に示すが，比較的よい近似を与える. また，図一8から，脆度係数は養生方法の影響をあまり 受けないと考えられる. 

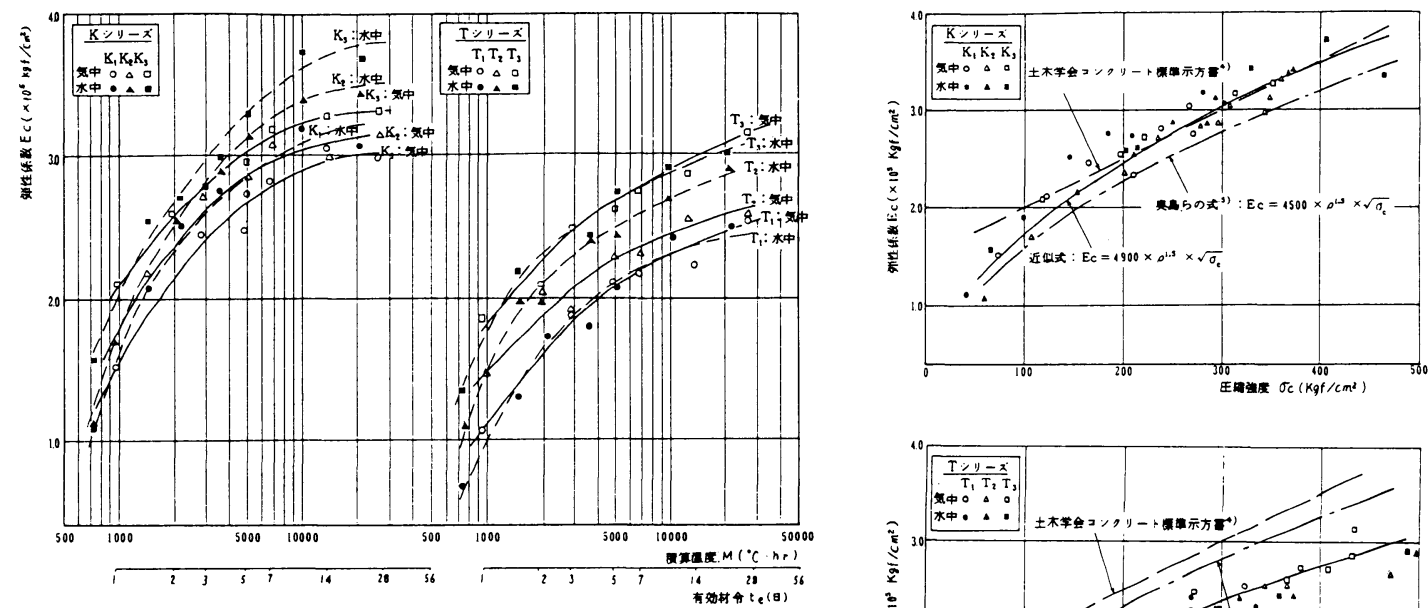

\section{図一10＼cjkstart圧縮弾性係数と糟算温度および有効材令との関係}

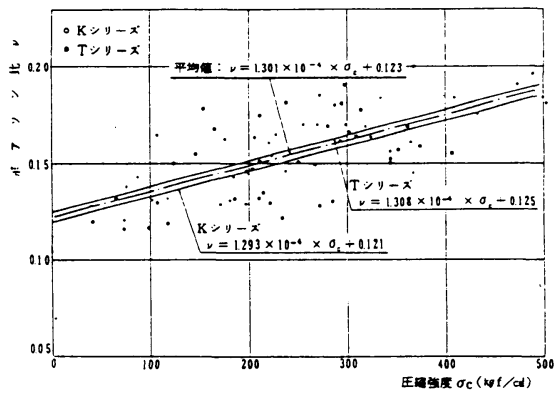

図一12 ポアソン比と圧縮強度の関係

このような結果から，マスコンクリートの割裂引張強 度は, まず, 標準水中養生された供試体の圧縮強度を, 前述した気中養生（マスコンクリートの養生に対応）に よる強度変化率により補正し, その補正した圧縮強度を もとに, 図一9 の $\sigma_{c} \sim \sigma_{s t}$ の関係から推定することがで きる.

\section{c ）圧縮弾性係数}

図一10に圧縮弾性係数と積算温度および材令の関係 を示す. 弾性係数の増加は若材令において顕著であり, 材令 1 日で 28 日の約 $1 / 2$ に達する. また, 弾性係数も 圧縮強度の発現亡同様に, 一般的に, 積算温度が約 1 $500^{\circ} \mathrm{C} \cdot \mathrm{h}$ 以下の若材令においては, 気中養生されたも のの方が水中養生されたものよりも大きくなるが, その 後は水中養生されたものの方が大きくなる.

また，圧縮強度と弾性係数の関係を図一11に示す. $K, T$ シリーズともに, 両者間の関係を $E_{c}=C \cdot \rho^{1.5}$ - $\sigma_{c}^{0.5}(C$ : 定数, $\rho$ : 比重) と仮定し近似式を求めると, 次のようになる.

$$
K \text { シリーズ : } E_{c}=4900 \rho^{1.5} \sigma_{c}^{0.5}
$$

$T$ シリーズ : $E_{c}=3790 \rho^{1.5} \sigma_{c}^{0.5}$

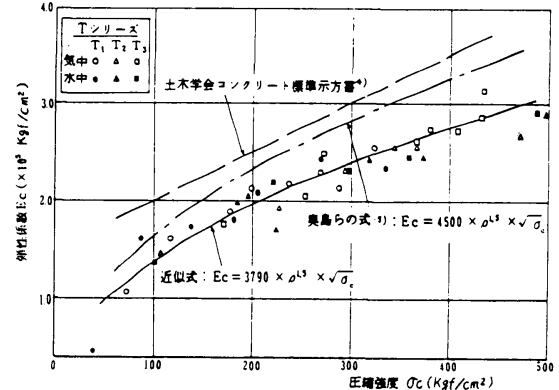

図一11 弾性係数と圧樎強度の関係

式（12）は従来の実験式 ${ }^{4), 5)}$ と比較してあまり差異は 認められないが, 式（13）はかなり小さめの值を与えて いる.これは, 主に粗骨材の弾性係数の違いによるもの と考えられる．このことは，コンクリートが骨材と母材 モルタルからなる二相複合材料であり，コンクリートの 弾性係数が骨材と母材モルタルの弾性係数によって顕著 な影響を受けることを示していると考えられる。

d) ポアソン比

図一12にポアソン比と圧縮強度の関係を示す。かな りばらつきはあるが，ポアソン比は王縮強度とともに増 加する傾向にあり，ポアンン比の値は $0.12 〜 0.20$ の範 囲にある.また，同図から，骨材および配合の相違によ る影響はほとんどないと考えられ，ポアソン比と圧縮強 度の関係は，平均的に次式により与えられる.

$\nu=1.301 \times 10^{-4} \sigma_{c}+0.123 \cdots$ ここに,

$\nu:$ ポアソン比

$\sigma_{c}:$ 圧縮強度 $\left(\mathrm{kgf} / \mathrm{cm}^{2}\right)$

\section{（2）純引張強度試験}

a ）純引張強度

配合別に各材令ごとの応力とひずみ関係を図一13に， 極限引張ひずみと積算温度および材令の関係を図一14 に示す，両図から；極限引張ひずみは材令とともに漸増 し, 材令 28 日では, $K$ シリーズで約 $100 \times 10^{-6}, T$ シリー

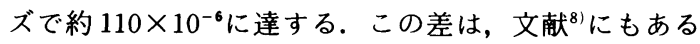
ように，主に骨材の影響と考えられる，また，図一14 

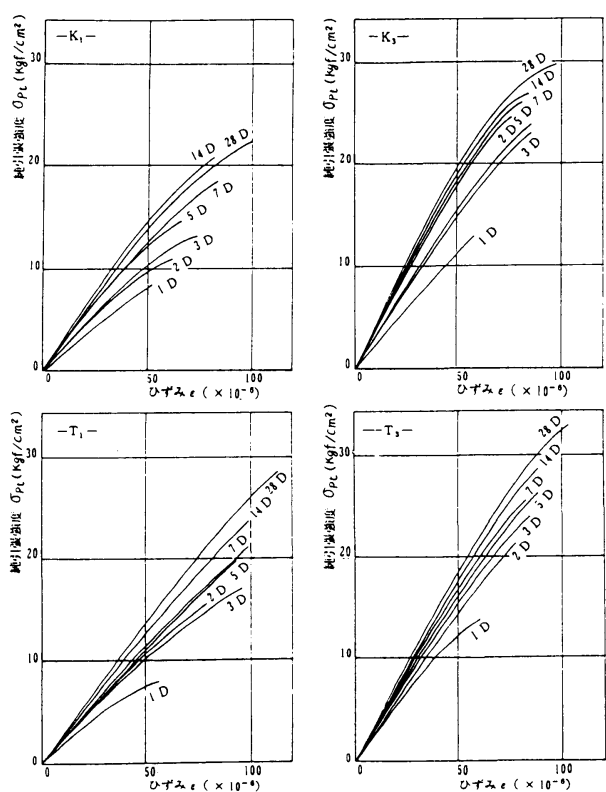

図一13純引張強度と引張ひずみとの関係

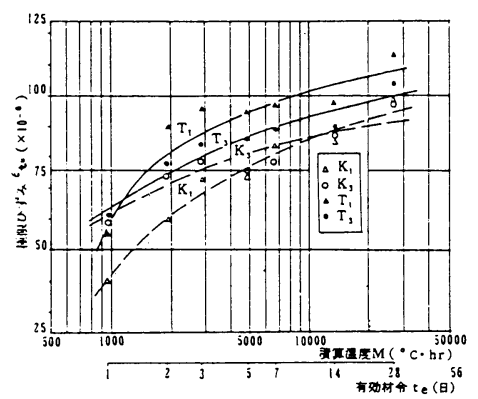

図一14 極限ひずみと樻算温度および有効材令との関係

から $W / C$ が大きくなると, 若材令時の極限引張ひずみ が小さくなる傾向にあることがわかる.

図一15に割裂引張強度および純引張強度と材令の関 係を, 図一16に引張強度比 $\sigma_{p t} / \sigma_{s t}$ 之積算温度および材 令の関係を, さらに, 図一17 に純引張強度と割裂引張 強度の関係を示す。

これらの図から，一般的に, 純引張強度は割裂引張強 度より小さく, その差は引張強度の増加, すなわち, 積 算温度の増加につれて漸増する傾向にある.これは, 純 引張強度の伸び率が, 割裂引張強度のそれに比べて小さ いことを示している. また，図一16 から，材令 28 日に おいて純引張強度は, 割裂引張強度に比べ $20 \sim 30 \%$ 低 くなる。これは既往の実験結果 ${ }^{6)}$ と同様な結果となった。 図一17 から，純引張強度と割裂引張強度との関係式を 求めると，次のように与えられる.

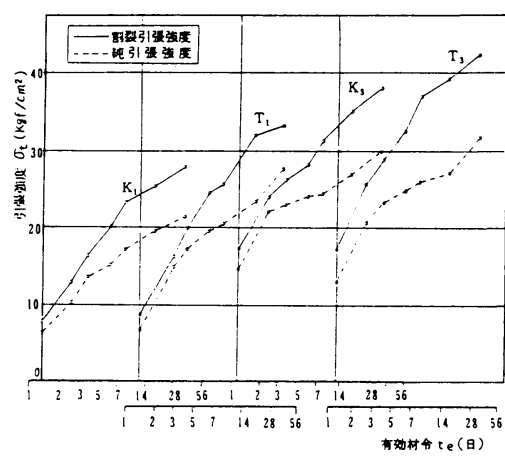

图一15引張強度と有効材令の関係

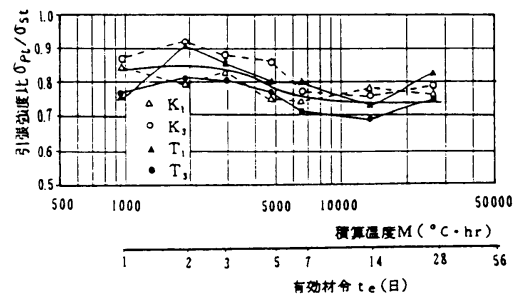

図一16 引張強度比と積算温度および有効材令との関係

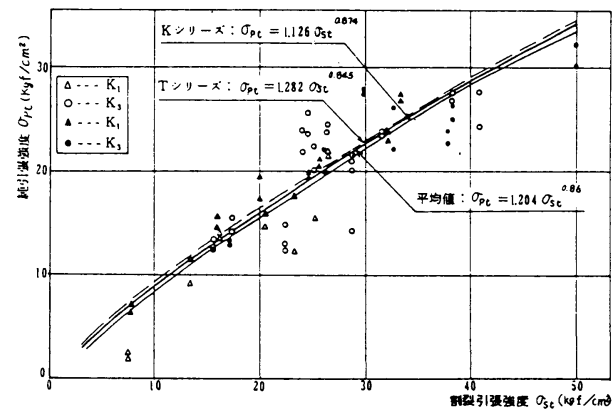

図一17 純引張強度と割裂引張強度との関係

$K$ シリーズ : $\sigma_{\rho t}=1.126 \sigma_{s t}^{0.874}$

$T$ シリーズ： $\sigma_{p t}=1.282 \sigma_{s t}^{0.845}$

両式は比較的近似しているため, この 2 式の平均値をと ると次式によって示される.

$\sigma_{p t}=1.204 \sigma_{s t}^{0.86}$.

いま, 割裂引張強度に対する純引張強度の低下率を $\beta^{\prime}$ とすると,

$$
\beta^{\prime}=\left(\sigma_{s t}-\sigma_{p t}\right) \times 100 / \sigma_{s t} \quad(\%)
$$

で表わされる．したがって，式（17）を代入して整理す ると,

$$
\beta^{\prime}=\left(1-1.204 / \sigma_{s t}^{0.14}\right) \times 100 \quad(\%)
$$

となる。この関係を図一18 に示す。なお，本試験では 割裂引張強度 $\sigma_{s t}$ は約 $7.5 \mathrm{kgf} / \mathrm{cm}^{2}$ 以上であり, 式 (17), （19）はこの範囲で有効である.

また, 図一19に従い標準水中養生供試体の割裂引張 


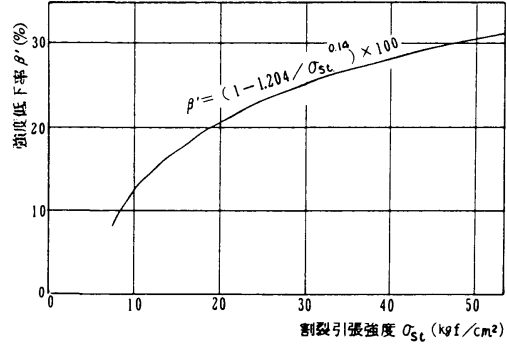

図一18 割裂引張強度に対する純引張強度の低下率と 割裂引張強度の関係

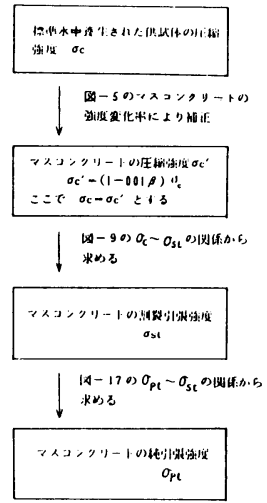

図一19 マスコンクリートの純引張強度の推定フロー困

強度から，マスコンクリートの純引張強度を推定する算 定式を求めると以下のようである.すなわち, 式 ( 2 ), (4)，(6)，(7)，(8)，(9) および（17）から，各 シリーズに対し，標準水中養生供試体の割裂引張強度に 対するマスコンクリートの純引張強度の比 $\gamma$ を求める と，次のように与えられる．

$\gamma=\sigma_{\text {ot }}^{a} / \sigma_{s t}^{w}=1.204\left(\sigma_{s t}^{a}\right)^{0.86} / \sigma_{s t}^{w}$

ここに, $K$ シリーズに対し,

$\sigma_{c}^{w}=8 \sigma_{s t}^{w} /\left(1-0.007 \sigma_{s t}^{w}\right)$

$\log M=\left(\sigma_{c}^{w}+215 C / W+229\right) /(101 C / W+53)$

$\beta=(6.1 C / W+2.4) \log M-(13.3 C / W+21.3)$

$\sigma_{c}^{a}=(1-0.01 \beta) \sigma_{c}^{w}$

$\sigma_{s t}^{a}=1 /\left(0.007+8 / \sigma_{c}^{a}\right)$

$T$ シリーズに対し,

$\sigma_{c}^{w}=8 \sigma_{s t}^{w} /\left(1-0.005 \sigma_{s t}^{w}\right)$

$\log M=\left(\sigma_{c}^{w}+338 C / W-2\right) /(149 C / W-35)$

$\beta=(5.9 C / W+0.1) \log M-(19.1 C / W-3.0)$

$\sigma_{c}^{a}=(1-0.01 \beta) \sigma_{c}^{w}$

$\sigma_{s t}^{a}=1 /\left(0.005+8 / \sigma_{c}^{a}\right)$

ここに，添字 $w$ および $a$ は，それぞれ水中養生および 気中養生（マスコンクリートに対応）を示す.

図一20は, 式 (20) から両シリーズの $\gamma$ を求めて,

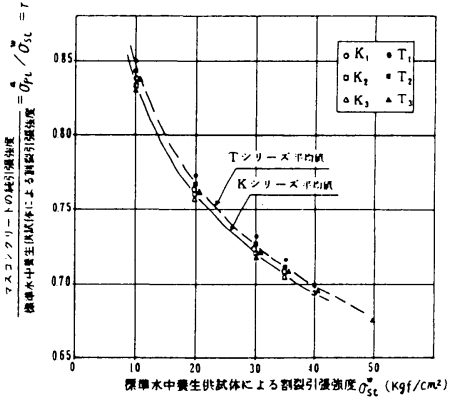

図一20 標準水中宾生供試体の割裂引張強度に対する マスコンクリートの純引張強度の比

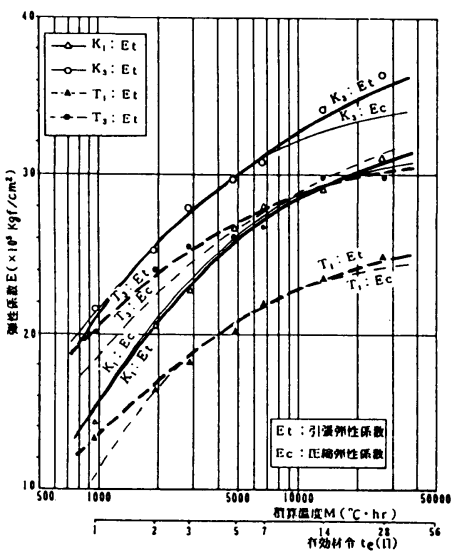

図一21弾性係数と積算温度および有効材令との関係

割裂引張強度 $\sigma_{s t}^{w}$ と関連づけたものである. 図から， $\gamma$ は両シリーズともに割裂引張強度の増加, すなわち, 材 令の増加とともに減少傾向にあることがわかる．実用の 範聿では, その減少率は約 15〜30\% 程度である.

このように，ある材令における標準水中養生供試体の 割裂引張強度から, 実際のマスコンクリートの純引張強 度を推定する場合，材料あるいは配合により相違すると も考えられるが，図一20に示す $\gamma$ により補正を行い算 定するのが一方法と考えられる.

b ) 引張弾性係数

図一21に，引張弾性係数と積算温度および材令の関 係を示す．図中に細線で前述の圧縮弾性係数も示すが， $K$ シリーズと $T$ シリーズを比較すると, 若材令におい て, 引張および圧縮弾性係数とも, その伸び率は $T$ シ リーズの方が小さくなる傾向にあることがわかる.

若材令時の弾性係数発現は, 複合材料としてのセメン トペーストの特性の影響が顥著で, 特に, このセメント ペーストと骨材の付着強度の大小に関係があると思われ る. したがって, この付着強度の大きな $T$ シリーズの 方が，この時期の弾性係数の発現割合が大きくなり，そ 


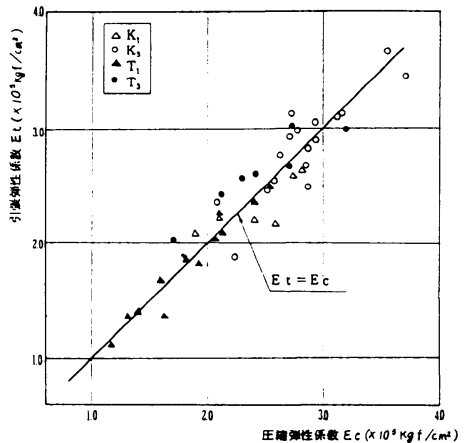

図一22 引張弾性係数と圧縮弾性係数の関係
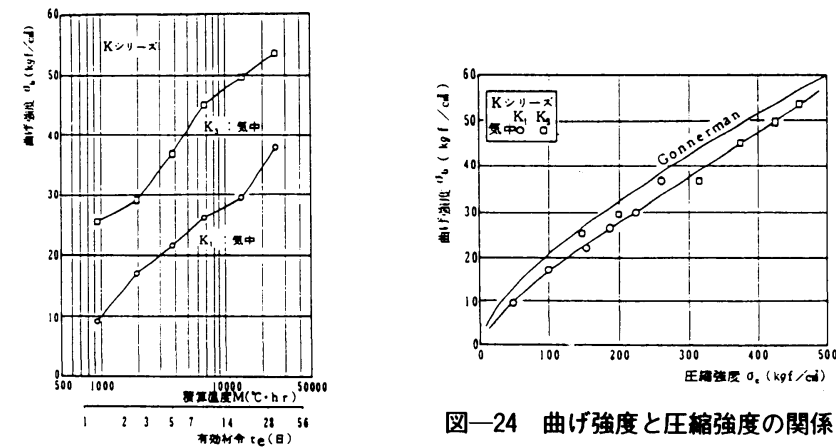

図一24曲げ強度と圧縮強度の関係

図一23曲げ強度と樌算温度および 有効材令との関係

の伸び率としては小さくなったものと考えられる.

また, 引張弾性係数 $E_{t}$ と圧縮弾性係数 $E_{c}$ の関係を 図一22 に示す. 従来の文献 ${ }^{61,71}$ は, 引張弾性係数は圧縮 弾性係数に比べて小さいとするものが多いが, 本研究で は,ほぼ同様となり次の関係式が得られた。

$$
E_{t}=E_{c}
$$

\section{（3）曲げ強度試験}

図一23に曲げ強度と積算温度および材令の関係を示 す，同図から，圧縮および引張強度の場合と同様，両者 の間にはほぼ直線関係が認められるが，比較的長期にお ける強度の伸びは,これらの強度の場合とは異なり，ほ とんど鈍化する傾向がないことがわかる.

また，図一24は曲げ強度と圧縮強度の関係を示す. 同図に, Gonnerman ${ }^{10)}$ の実験結果も示すが, 本試験の結 果は，これとほぼ類似している．また，配合による差は ほとんどみられない。

\section{（4） 熱膨張係数測定試験}

図一25に，各種骨材を用いたコンクリートの硬化過 程における自由膨張時, および収縮時の温度とひずみの 関係を示す．図に示されるように，いずれのシリーズの 場合も，温度上昇過程においては，凝結前後に曲線の勾 配が大きく変化している.これは, 凝結前の熱膨張係数 がかなり大きいことを示している.すなわち, セメント ペーストの熱膨張係数は $(10 \sim 20) \times 10^{-6} /{ }^{\circ} \mathrm{C}$ 程度であ り，骨材のそれは $(6 \sim 12) \times 10^{-6} /{ }^{\circ} \mathrm{C}$ 程度 ${ }^{9)}$ であるから， 凝結前の温度変化量約 $5^{\circ} \mathrm{C}$ 以下 $\left(\boldsymbol{M} \leqq\right.$ 約 $\left.300^{\circ} \mathrm{C} \cdot \mathrm{h}\right)$ の ごく若材令時のコンクリートの熱膨張機構は, セメント ペーストに大きく依存していると考えられる．また，同 図にみられるように，各種コンクリートのひずみと温度 の関係は, 近似的に 3 本の直線により示され，しかも， 温度安定時の収縮ひずみは，骨材の種類によって大きく 異なることがわかる．このような結果から，実際のマス コンクリート構造物においては, 同一の温度変化に対し ても，使用骨材により温度安定時の収縮ひずみが大きく

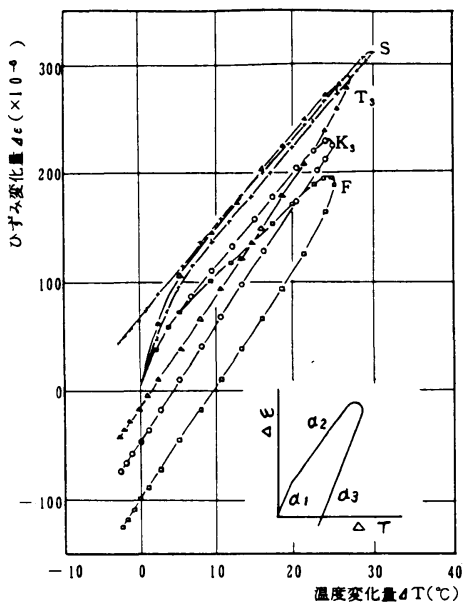

図一25各程骨材を用いたコンクリートの硬化過程 における温度とひずみの関係

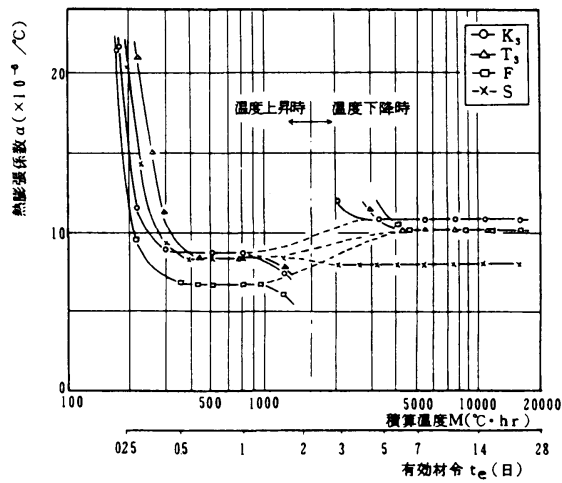

図一26各種骨材を用いたコンクリートの熱㱆張係数の 経時変化

異なることが予想される。

図一25で，各曲線の種々の材令における接線として 求めた熱膨張係数の経時変化を図一26に示す。同図に 


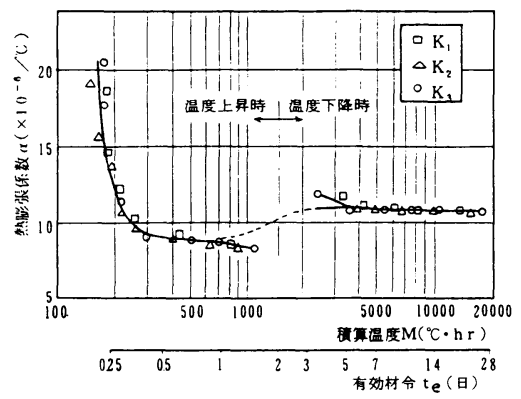

図一27 $K$ シリーズの熱膨張係数の経時变化

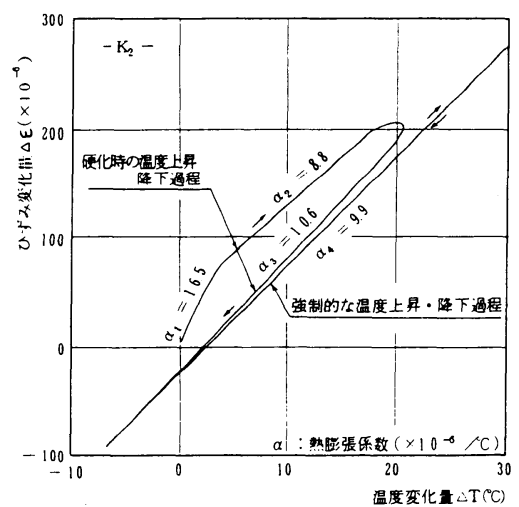

図一28硬化時および強制的な温度变化時における 温度とひずみの関係

みられるように, 熱膨張係数は疑結前後で大きく変化し， 最高温度到達前にある一定值に達した後, 温度降下過程 に入り, 人工軽量骨材の場合を除き，これより幾分大き な一定值をとる.なお, 同図の破線の区間は, 図一25 において温度が上昇から下降に変化し， $\Delta \varepsilon \sim \Delta t$ の関係 がループとなる区間である.骨材により,このようなルー プ形状はかなり異なっており，このような現象がコンク リートのいかなる特性により生じるか不明であり, 今後 の研究課題と考えられる.

図一27は, $K$ シリーズの熱膨張係数の経時変化を示 す.一般に，熱膨張係数は単位セメント量を増すと大き くなる3)といわれているが, 本研究の範囲 $(C=225$ $\left.342 \mathrm{~kg} / \mathrm{m}^{3}\right)$ では，ほぼ同等とみなしてよいと考えられ， 温度上昇時で $(20 \sim 8.8) \times 10^{-6} /{ }^{\circ} \mathrm{C}$, 下降時で約 $10.6 \times$ $10^{-6} /{ }^{\circ} \mathrm{C}$ となった。

図一28は, $K_{2}$ において温度が降下し安定した後, 温 床線により加熱し, コンクリート温度を再度上昇・下降 させた場合のひずみと温度の関係を示す. 再温度履歴時 の熱膨張係数は, 上昇および下降時ともほぼ同様で, そ の值は初期温度下降時の値より幾分小さくなった.

\section{4. まと め}

本研究は, マスコンクリートの諸物性を明確にする目 的で行ったものであり, 今回の研究で得られた結果を要 約すると, 以下のようである.

（1）一般に，マスコンクリートの圧縮および割裂引 張強度は, 標準水中養生されたそれらの值に比べ, 有効 材令約 1.5 日程度のごく若材令においては大きく, 逆に, それ以後においては小さくなる. この強度変化率は, 富 配合のコンクリートほ亡゙, すなわち, $W / C$ の小なるほ ぼ，材令の増加とともに大きくなる傾向にある.

（2）標準水中養生およびマスコンクリートの圧縮強 度は, $C / W$ をパラメーターとして一般形 $\sigma_{c}=A \log$ $M-B$ で, 割裂引張強度は, 圧縮強度をパラメーター として一般形 $\sigma_{s t}=1 /\left(C+D / \sigma_{c}\right)$ で近似されるものと推 定される.

（３）純引張強度は割裂引張強度に比べ小さく, 両者 の関係は $\sigma_{p t}=1.204 \sigma_{s t}^{0.86}$ によって示すことができる. また, その低下率は材令の増加とともに大きくなり, 材 令 28 日で約 $20 \sim 30 \%$ 程度となる. $0.1 \sim 0.2 \mathrm{kgf} / \mathrm{cm}^{2} / \mathrm{s}$ の漸増引張過程におけるマスコンクリートの極限引張ひ ずみは, 材令の増加とともに大きくなり, 材令 28 日で

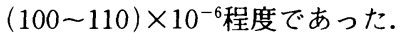

（4）マスコンクリートの弾性係数も，一般のコンク リートと同様, 圧縮強度と関係づけることができるが, この圧縮強度は, マスコンクリートの影響による強度変 化率を導入し補正する必要がある. また, 引張弾性係数 と圧縮弾性係数はほぼ同等であった。

（5）圧縮過程におけるポアンン比は,ばらつきは大 きいが, 圧縮強度との間にはほぼ直線関係が認められ, $\nu=1.301 \times 10^{-4} \sigma_{c}+0.123$ によって示すことができる.

（6）各種骨材を用いたマスコンクリートの硬化過程 における熱膨張係数は, 材令の経過とともにかなり大き く変化するが, 近似的には 3 種の値で表示することがで きる.これらの值は, 一般的に, 温度上昇時の凝結前後 で大きく変化した後, 最高温度到達までにある一定值を とり, その後, 温度下降過程に入ると, これより幾分大 きな値となる.

（7）川砂利使用の場合に比べ，砕石を使用した場合 は脆度係数が小さくなり，しかも，極限ひずみが増大す る.すなわち, 砕石使用により, 引張強度および引張ひ ずみ能力ともに向上する傾向がある. また，弾性係数に おいては, 骨材の影響が䫓著にみられたが,これは主に， 骨材自身の弾性係数の差に基づくものと考えられる.

（8）以上の事項をもとに, マスコンクリートの諸物 性を求める方法を, 以下のように提案した。

a ) 圧縮強度 $\sigma_{c}$, 割裂引張強度 $\sigma_{s t}$ および純引張強 
度 $\sigma_{\rho t}$

これらは, 図一19のフロー図に従い求めることがで きる。

b ） 極限引張ひずみ $\varepsilon_{t u}$

図一14の $\varepsilon_{t u} \sim M$ の関係から求めることができる.

c ) 圧縮弾性係数 $E_{c}$ および引張弾性係数 $E_{t}$

骨材により相違することが考えられるため，実験によ り求めるのが好ましいが近似的には図一11より求める ことができる.また， $E_{c}=E_{t}$ としてよい.

d) ポアソン比 $\nu$

図-12の $\nu-\sigma_{c}$ の関係から求めることができる.

e ) 熱膨張係数 $\alpha$

骨材により相違することが考えられるため，実験ある いは他の実験結果より求めるのが好ましいが，その経時 変化は図一26のようである.

謝辞：本研究を行うにあたり，日本国土開発 (株) 近藤時夫博士から貴重な助言とご指導を受けた。また， 同技術研究所の浅沼 潔および横田季彦氏に，実験なら びにデータのまとめに関し多大のご協力をいただいた。

これらの皆様に厚く感謝の意を表します.

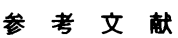

1）岡田 清・小林和夫・宮川豊章・村本吉弘：マスコンク リートの基本的特性に関する一考察，セメント技術年報,
第 34 号, pp. 230 233, 1980.

2）横道英雄・藤田嘉夫：鉄筋コンクリート工学, pp. 25, 共立出版, 1978.

3）岡田 清・六車 熙: コンクリート工学ハンドブック, pp. 398, 朝倉書店, 1981.

4) 土木学会：コンクリート標準示方書, pp. 23, 1980.

5）奥島正一・小坂義夫：人工軽量骨材コンクリートの力学 的性質，材料，Vol. 15，No. 157，pp. 691 698， 1966.

6）児島孝之・矢村 潔：コンクリートの引張特性に関する 2,3 の実験, セメント技術年報, 第 25 号, pp. 249 253, 1971.

7）児島孝之・矢村 潔・浦沢義彦：引張応力下におけるコ ンクリートの力学的特性について, セメント技術年報, 第 24 号, pp. 290 295, 1970.

8) Houghton, D. L. : Determining Tensile Strain Capacity of Mass Concrete, ACI Journal, Vol.73, No. 12, pp. 691 700, Dec. 1976.

9) Neville, A. M. (後藤幸正・尾坂芳夫訳)：コンクリート の特性, pp. $370 \sim 374$, 技報堂出版, 1979 .

10）近藤泰夫・坂 静雄 : コンクリート工学ハンドブック, pp. 307 312, 朝倉書店, 1965 .

11） Rüsch, H. (百島祐信訳)：コンクリート構造物のクリー プと乾燥収縮, pp. 31 34, 鹿島出版会, 1976.

12）竹下治之・浅沼 潔・横田季彦：マスコンクリート物性 の基礎的特性について, マスコンクリートの温度応力発 生メカニズムに関するコロキュウム論文集, pp. 27〜34, 日本コンクリート工学協会, 1982.

(1984. 2. 2 - 受理) 